\title{
El efecto de la educación deportiva en el comportamiento de estilo de vida saludable de los estudiantes universitarios
}

\author{
The Effect of Sports Education on University Students' Healthy Life Style Behavior
}

Ozlem Demirtas ${ }^{1 \mathrm{a}}$

Hitit University, Turkey ${ }^{1}$

ORCID ID: https://orcid.org/0000-0002-9369-66701

Recibido: 23 de junio de 2021

Aceptado: 13 de setiembre de 2021

\section{Resumen}

El objetivo de este estudio es investigar el efecto de la educación deportiva en los hábitos de vida saludables de los estudiantes universitarios. La muestra del estudio estuvo formada por 234 mujeres y 249 varones. Se utilizó la prueba T en los cálculos estadísticos. En el estudio, el puntaje promedio de la Escala de comportamiento de estilo de vida saludable II es 134.5 puntos para las mujeres y 136.6 puntos para los hombres. Nuevamente, la puntuación total de la escala, mientras que es 128,4 para quienes no reciben educación deportiva; es de 139,1 para los estudiantes que reciben formación deportiva. Según género, se encontraron diferencias significativas género en desarrollo mental, nutrición, actividad física, responsabilidad en la salud, relaciones interpersonales y manejo del estrés $(\mathrm{p}<0.05$ ). Asimismo, los estudiantes que recibieron educación deportiva obtuvieron puntajes significativamente más altos en desarrollo mental, nutrición, actividad física, responsabilidad con la salud, relaciones interpersonales, manejo del estrés y puntajes de escala total que los estudiantes que no recibieron entrenamiento deportivo ( $\mathrm{p}<0.05 \mathrm{yp}<0,001$ ). Como resultado, se observa que la educación deportiva incide positivamente en los comportamientos de estilo de vida saludable de los estudiantes universitarios.

Palabras clave: Estudiantes universitarios, sedentario, educación deportiva, actividad física, estilo de vida.

\footnotetext{
Abstract

The aim of this study is to investigate the effect of sports education on healthy lifestyle behaviors of university students. The sample of the study consisted of 234 female and 
249 male participants. T-test was used in statistical calculations. In the study, the average score of the Healthy Life Style Behavior Scale II is 134.5 points for women and 136.6 points for men. Again, the scale total score is 128.4 for those who do not receive sports

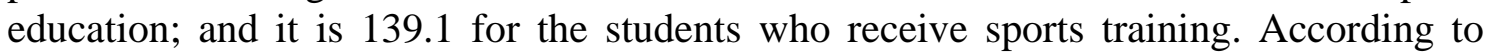
gender, significant differences were found according in mental development, nutrition, physical activity, health responsibility, interpersonal relationships, and stress management $(\mathrm{p}<0.05)$. Likewise, students who received sports education had significantly higher scores on mental development, nutrition, physical activity, health responsibility, interpersonal relationships, stress management, and total scale scores than students who did not receive sports training ( $\mathrm{p}<0.05$ and $\mathrm{p}<0.001)$. As a result, subdimensions differ in perception of healthy lifestyle behaviors among university students. It is observed that sports education positively affects the healthy lifestyle behaviors of university students.

Keywords: University Students, sedentary, sports education, physical activity, lifestyle.

\section{Introduction}

According to the definition of the World Health Organization (WHO), health is not only the absence of illness or disability, but also a state of complete physical, mental and social well-being (O'Donnell, 2009). A healthy lifestyle enables people to control their behaviors that may affect their health and regulate their daily activities (İmamoğlu et al.,2018). Human beings need to know how to control all behaviors that affect their health, to choose daily activities appropriate for them and how to feed (Savucu, 2020). For the other hand, optimal health is defined as a dynamic balance between being in physical, emotional, social, positive emotions / at peace with itself and intellectual health. In the physical field; exercise, nutrition, medical self-care, substance abuse control, in the emotional sphere; emotional crisis care, stress management, in the social field; societies, families, and friends take place. Again, in the intellectual field; education, success, career development and in the being positive field; the concepts of love, hope, and helpfulness are included (O'Donnell, 2009).

It is stated that the environment of the individual is effective in the formation of behavior, and the level of knowledge and skill of the individual is effective in gaining behavior (Volden et al., 1990; Bottorf et al., 1996; Palank, 1991). Healthy life style behaviors include taking responsibility for the protection and improvement of human health, adequate and balanced nutrition, coping with stress, regular exercise, mental development and interpersonal relationships (Walker et al., 1987). 
For the other hand, the healthy lifestyle behaviors scale can be used to determine health promotion behaviors and evaluate the effectiveness of programs to be planned for this purpose. There are 6 sub-dimensions in the scale, these mental development (spirituality), nutrition, physical activity, health responsibility, interpersonal relationships and stress management. Mental development; one's life goals, individual selfimprovement ability and to what extent one's self-awareness and satisfaction and nutrition; choosing and organizing a person's meals determines their value in choosing food. Physical activity; While showing to what extent exercise practices, which are an essential element of healthy life, are applied by the individual, health responsibility; determines the level of responsibility of the individual for his / her own health and the level of participation in his/her health. Interpersonal relationship; the individual's communication and continuity level with his/her immediate environment and stress management; it determines an individual's level of recognition of stress sources and stress control mechanisms (Bahar et al., 2008; Bozhüyük, 2010).

Quality of life holds an important place among the most important indicators of gaining health (Savucu, 2020). Especially the university education process, as a period in which important changes and developments are experienced in the lives of individuals; it affects both health behaviors and personality traits in individual life and their orientation towards vocational education and success (Turan et al., 2018). The aim of this study is to investigate the effect of sports education on the healthy life style behaviors of university students. It is thought that getting sports education has a positive effect on students' healthy living behaviors. As a result of this study, the effect of sports education on healthy lifestyle behaviors of university students in the Turkish population will be reflected in the sports literature.

\section{Methodology}

\section{Participants}

The sample of the study consisted of 234 female and 249 male university students. While 160 of the students were students studying at the Faculty of Education (who did not receive sports education), 323 of them were students of the Faculty of Sports Sciences. The data were collected anonymously using a questionnaire form and the Healthy Life Style Behaviors Scale II. Students voluntarily filled out the questionnaires. Sickness 
status was also asked in the personal information questionnaire. Those with a permanent disease and cardiovascular diseases were excluded from the study. Sickness status was also asked in the personal information questionnaire. Those with a permanent disease and cardiovascular diseases were excluded from the study.

\section{Healthy Life Style Behaviors Scale}

In this study, demographic information as data collection tools and Healthy Lifestyle Behaviors Scale developed by Walker, Sechrist and Pender (Walker et al., 1987) was used. The scale was later revised by Walker et al. in 1996, and by adding 4 more items, the Healthy Life Style Behaviors Scale II, consisting of 52 items, was created. The validity and reliability of the questionnaire was tested on the Turkish population.

The validity and reliability study of the scale in our country was conducted by Bahar et al. (2008). The scale consists of 52 items and has 6 sub-factors. Subgroups are mental development (spirituality), health responsibility, physical activity, nutrition, interpersonal relationships, and stress management. The scale consists according to the four-point Likert. It is evaluated with never 1, sometimes 2, often 3, and regularly 4 points. The higher the scores obtained from the scale indicate that the individual applies the specified health behaviors at a high level.

\section{Subscales and related items}

Nutrition subscale has 9 items $(2,8,14,20,26,32,38,44$ 50);

Physical activity subscale includes 8 items (4, 10, 16, 22, 28, 34, 40, 46);

Interpersonal relations subscale has 9 items $(1,7,13,19,25,31,37,43,49)$;

Health responsibility subscale 9 items $(3,9,15,21,27,33,39,45,51)$, Stress management subscale 8 items $(5,11,17,23,29,35,41,47)$;

Mental development subscale has 9 items (6, 12, 18, 24, 30, 36, 42, 48, 52).

The lowest score is 52, the highest score is 208. Healthy Lifestyle Behaviors Scale II considering the evaluation of the validity and reliability of the Healthy Lifestyle Behaviors Scale II; Kendal W concordance test was conducted for content validity. As a result of the test, it was determined that there was a consensus among the experts and it was determined that it represented the area to be measured. Alpha reliability of the scale 0.94. Alpha of the sub-factors of the scale coefficient reliability value is between 0.79 0.87 it is changing. (Bahar et al., 2008). Within the scope of the data collected in this 
study, the scale was also The Cronbach Alpha internal consistency coefficient was calculated and found to be 0.91 . Regarding to research permission, it was obtained from the Social and Human Sciences Ethics Committee of Ondokuz Mayıs University in 2020.

\section{Statistical Processes}

SPSS 25.00 package program was used for statistical processes. The data obtained from the scale were calculated in accordance with the scoring directive. While evaluating the data, its suitability to normal distribution was investigated with the "Kolmogorov Smirnov Test" and it was found that all data were distributed normally. T-test was used in statistical calculations. Means are given with standard deviation and statistical significance was evaluated as $\mathrm{p}<0.05$.

\section{Results}

Anthropometric characteristics of the participants are given in Table 1. In Table 2, data on healthy lifestyle behaviors by gender are compared. In Table 3, the comparison of healthy lifestyle behaviors according to the type of faculty attended.

\section{Table 1}

Comparison of students' anthropometric characteristics according to gender

\begin{tabular}{clcccc}
\hline Variables & Gender & N & Mean & $\begin{array}{c}\text { Std. } \\
\text { Deviation }\end{array}$ & P \\
& & & & & \\
\hline \multirow{2}{*}{ Age (years) } & Women & 234 & 21,25 & 0,14 & $-5,46^{* *}$ \\
& Man & 249 & 22,80 & 0,15 & \\
Height $(\mathrm{cm})$ & Women & 234 & 166,53 & 0,71 & $-5,14^{* *}$ \\
& Man & 249 & 174,01 & 0,50 & \\
Weight $(\mathrm{kg})$ & Women & 234 & 62,10 & 0,74 & $-11,17^{* *}$ \\
& Man & 249 & 72,50 & 0,66 & \\
\multirow{2}{*}{$\mathrm{BMI}\left(\mathrm{kg} / \mathrm{m}^{2}\right)$} & Women & 234 & 22,54 & 0,18 & $-9,02^{* *}$ \\
& Man & 249 & 23,95 & 0,16 & \\
\hline
\end{tabular}

The average age of the students participating in the study was 21.25 years for women and 22.80 years for men (Table 1). A statistically significant difference was found 
between the age, height, body weight and body mass index values of the students according to gender $(\mathrm{p}<0.001)$.

Table 2

Comparison of healthy lifestyle behaviors by gender

\begin{tabular}{|c|c|c|c|c|c|}
\hline Sub-group & Gender & $\mathbf{N}$ & Mean & $\begin{array}{c}\text { Std. } \\
\text { Deviation }\end{array}$ & $\mathbf{P}$ \\
\hline \multirow{2}{*}{ Nourishment } & Women & 234 & 21,95 & 4,19 & \multirow{2}{*}{$-2,08 *$} \\
\hline & Man & 249 & 21,12 & 4,56 & \\
\hline Physical & Women & 234 & 20,96 & 4,69 & \multirow{2}{*}{$-2,56 *$} \\
\hline Activity & Man & 249 & 22,08 & 4,92 & \\
\hline Interpersonal & Women & 234 & 25,31 & 4,46 & \multirow{2}{*}{$2,26^{*}$} \\
\hline Relation & Man & 249 & 24,23 & 5,82 & \\
\hline Health & Women & 234 & 20,95 & 3,96 & \multirow{2}{*}{$-2,75^{*}$} \\
\hline Responsibility & Man & 249 & 22,01 & 4,42 & \\
\hline Stress & Women & 234 & 20,60 & 4,22 & \multirow{2}{*}{$-2,39 *$} \\
\hline Management & Man & 249 & 21,53 & 4,30 & \\
\hline Mental & Women & 234 & 24,69 & 4,81 & \multirow{2}{*}{$-2,04 *$} \\
\hline Development & Man & 249 & 25,61 & 5,05 & \\
\hline \multirow{2}{*}{ Total Score } & Women & 234 & 134,46 & 19,52 & \multirow{2}{*}{1,12} \\
\hline & Man & 249 & 136,58 & 21,73 & \\
\hline
\end{tabular}

$* \mathrm{p}<0.05 \quad * * \mathrm{p}<0.001$

There were statistically significant differences between the life style behavior subdimensions of the students who participated in the study $(\mathrm{p}<0.05)$. 
Table 3

Comparison of healthy life style behaviors according to sports education status

\begin{tabular}{cccccc}
\hline Sub-group & Faculty & N & Mean & $\begin{array}{c}\text { Std. } \\
\text { Deviation }\end{array}$ & P \\
& Education & 160 & 20,83 & 5,56 & $-2,45^{*}$ \\
Nourishment & Sports Sciences & 323 & 21,86 & 3,65 & \\
Physical & & 160 & 20,09 & 6,31 & $-4,73 * *$ \\
Activity & Education & 323 & 22,26 & 3,71 & \\
Interpersonal & Sports Sciences & 160 & 22,83 & 6,54 & $-5,88 * *$ \\
Relations & Education & 323 & 25,71 & 4,13 & \\
Health & Sports Sciences & 160 & 20,31 & 5,24 & $-4,12 * *$ \\
Responsibility & Education & 323 & 22,08 & 3,50 & \\
Stress & Sports Sciences & 160 & 20,39 & 5,75 & $-2,51 *$ \\
Management & Education & 323 & 21,42 & 3,29 & \\
Mental & Sports Sciences & 160 & 23,99 & 6,67 & $-3,71 * *$ \\
Development & Education & 323 & 25,74 & 3,70 & \\
Total Score & Sports Sciences & 160 & 128,44 & 28,37 & $-5,73 * *$ \\
& Education & 323 & 139,08 & 14,35 & \\
\hline * $<<0.05$ & & & & &
\end{tabular}

Significant differences were found in the sub-dimensions of healthy lifestyle behaviors and total scores according to the field of education of the students participating in the study ( $\mathrm{p}<0.05$ and $\mathrm{p}<0.001)$.

\section{Discussion}

The average age of female students participating in the study is 21.3 years, while male students are 22.8 years. While the average height of the students is $166.5 \mathrm{~cm}$ for women, it is $174.01 \mathrm{~cm}$ for male students. Body weight is $62.1 \mathrm{~kg}$ for female students and $72.5 \mathrm{~kg}$ for male students. Body mass index in the study was found as $22.5 \mathrm{~kg} / \mathrm{m}^{2}$ for female students and $23.9 \mathrm{~kg} / \mathrm{m}^{2}$ for males. If the body mass index values are between $20-25 \mathrm{~kg} / \mathrm{m}^{2}$, it is considered within the criteria of being healthy (Atan \& İmamoglu, 2020). According to this evaluation, students' BMI is within the limits accepted as normal. There was a difference in favor of males in terms of age, height, body weight, and body mass index of the Faculty of Education students participating in the study ( $p<0.01$ ). In this study, the total score obtained from the scale was determined as 134.5 for women and 136.6 for men. In this study, the total scale score of students who do not receive sports education was 128.44 , while it was found to be 139.08 who receive. 
In a study conducted by Cihangiroğlu and Deveci (2011), healthy lifestyle behaviors in students were found to be 121.75 points on average. For his part, Bozhöyük (2010), found the mean total score of the scale 124.30 in his study and stated that this score is medium level. In a study by Şen et al. (2017), healthy lifestyle behaviors were found to be 118.00 points on average in students. İmamoğlu et al. (2018) found 122.56 points for women and 123.42 points for men in a study they conducted. In another study by Çebi and İmamoğlu (2018), they found the scale total score as 137.34. Özyazıcıoğlu et al. (2011) found that nutrition and interpersonal relations subscale scores were higher in female students and the difference between groups was statistically significant. Kafkas et al. (2012) stated that female teachers have higher healthy lifestyle behavior scores than male teachers and there is a statistically significant difference between scale scores according to gender. Şimşek et al. (2012) found no significant difference between subdimensions and gender in their study.

It is worth highlighting the study of K1lıç (2017), who found that there is a slight difference in favor of women in healthy lifestyle behaviors of physical education teachers. In the study of Sural and Tamer (2021), the general average scores of physical education teachers for healthy lifestyle behaviors do not show a significant difference according to gender. In the study conducted by Asiabi (2012), no significant difference was found between men and women in terms of total scores of healthy lifestyle behaviors in physical education and sports students. In another study, no statistically significant difference was found between female and male student groups in terms of health responsibility, mental development and stress management subscales, but the average scores of the exercise, nutrition and interpersonal relations subscale of men were observed to be higher than that of women (Volkan, 2016).

In the study of Bozhüyük (2010), it was observed that male students had higher mean scores in the physical activity subscale, and lower scores in health responsibility, nutrition, mental development, interpersonal relationships and stress management subscales according to students' gender. Demir et al. (2015) in a study conducted with university students; It was determined that female students had significantly better scores than males in nutrition, interpersonal relationships, health responsibility subscales and total mean scores. In a study conducted by Karadamar et al. (2014) with high school students, nutrition and exercise subscale scores of boys were found to be higher than girls. 
In the study of Karadeniz et al. (2008), health responsibility scores of female students were found to be higher than that of boys.

Özbaşaran et al. (2004) also found that female students' mean scale scores were higher than boys. Zaybak and Fadiloğlu (2004) also found that female students' mean scale scores were higher than boys, but they did not find statistically different. In the study of Çebi and İmamoğlu (2018), when the mean scores of the total scale and subgroups of the students were examined, health responsibility behaviors, physical activity behaviors, nutritional behaviors, interpersonal relationship behaviors, stress management behaviors showed statistically significant differences according to their gender.

In the study conducted by Kocaakman (2010), women's mental development, health responsibility, and interpersonal relationship mean scores were found to be higher than male students. Physical activity means score for male students was found to be higher than female students. For its part, İmamoğlu et al. (2018) found no significant difference in mental development, stress management subscale and total scale scoring in their study. On the other hand, they found a significant difference in nutrition, physical activity, health responsibility and interpersonal relationships sub-dimensions. In this study, a significant difference was found by gender in mental development, nutrition, physical activity, health responsibility, interpersonal relationships and stress management $(\mathrm{p}<0.05)$. The difference in total score is not statistically significant ( $p>0.05)$. The scores of men are higher in mental development, physical activity, health responsibility, stress management and total score. Women score higher in nutrition and interpersonal relationships.

It can be said that female students pay more attention to their nutrition than male students, but they are weaker in controlling their stress. In this study, physical activity scores of men are higher than women. It can be interpreted that men mostly spend more time on exercise than women. Again, in this study, women; compared to men, it is observed that they stand out in nutrition, health responsibility and interpersonal support subscales. These results can be thought as men are more active and women pay more attention to their lives in terms of nutrition and responsibility than men.

In some studies, the health responsibility and health behaviors of girls compared to boys are due to the role of women in our traditional culture. It may also be due to the fact that women have fewer tendencies to take risky behaviors than men (Çebi \& 
İmamoğlu, 2018). In this study, the total scale score of students who do not receive sports education was 128.44 , while it was found to be 139.08 in sports education subjects. The higher scores on the scale indicate that the individual applies the specified health behaviors at a high level (Bahar et al., 2008). Accordingly, the healthy lifestyles of students who receive sports education are better than those who do not receive sports education. In a study conducted by Türkay (2020), the value that students give to their bodies and themselves increased with their participation in sports activities. Therefore, it was stated that attitudes, expectations and satisfaction levels about life lead to positive physical changes. Regular exercise is of great importance in preventing disease. It strengthens the immune system and enables it to fight viruses and bacteria (Yalcin et al.,2020). In this study, the mental development, nutrition, physical activity health responsibility, interpersonal relationships, stress management and total scale scores of the students who received sports education were significantly higher than the students who did not receive sports training ( $\mathrm{p}<0.05$ and $\mathrm{p}<0.001)$.

Although this study shows new information about the effect of sports education on healthy lifestyle behaviors of university students, it has some limitations. First of all, the Healthy Lifestyle Behaviors Scale developed by Walker et al. was used in studies on healthy lifestyle behaviors. The Turkish adaptation of the scale was last done by Akça in 1998, and the validity and reliability study of the scale in our country was carried out by Bahar et al., (2008). In order for the scale to be used effectively in the evaluation of health behaviors of various groups and in evaluating the effectiveness of planned health promotion programs, the Turkish validity and reliability study of the scale needs to be readapted.

Another point is the fact that the participants are university students also includes the adaptation process from high school to adulthood. In addition, it is a fact that students who start university in a different city suddenly find themselves in a different environment and their lifestyles are affected. It is thought that it would be beneficial to carry out qualitative studies as well as quantitative studies in order to determine the factors affecting the health behaviors of individuals and to learn the underlying causes of these factors in depth. 


\section{Conclusion}

In terms of perception of healthy lifestyle behaviors among university students, a difference was found in subscales by gender. It was concluded that receiving sports training positively affected the healthy lifestyle behaviors of university students. It is recommended that university students who do not have sports training should be supported in terms of being active in sports.

For the other hand, recreational sports and health protection and development courses should be included in the curriculum of universities. In addition, it is recommended that university communities and campus recreation take an active role in determining the subjects they lack knowledge and behavior (sports, active and healthy life, coping with stress, nutrition, etc.).

\section{References}

Asiabi S. A. (2012). Beden eğitimi ve spor yüksekokulu öğrencilerinde fiziksel aktivite alışkanlıkları ve sağlıklı yaşam biçimi davranışlarının akademik başarı ile ilişsisi. Ankara üniversitesi Sağlık bilimleri Enstitüsü, Beden eğitimi ve spor anabilim dalı Yüksek lisans tezi, Ankara. https://tez.yok.gov.tr/UlusalTezMerkezi/

Atan T., \& İmamoğlu O. (2020). Nutritional Habits According to Gender, Stage of Exercise Behavior and BMI, Turkish Journal of Sport and Exercise, 22 (3), 505512. DOI: $10.15314 /$ tsed.691983

Bahar Z., Beşer A., Gördes N., Ersin F., \& Kıssal A., (2008). Healthy life style behavior scale ii:a reliability and validity study. Journal of Cumhuriyet University School of Nursing, 12 (1), 1-13. https://academicji.org/dergindex/?dergi_id=7585249bb17512\&id=1

Bottorff J. L., Johnson J. L., Ratner P. A., \& Hayduk L. A., (1996). The effects of cognitive-perceptual factors on health promotion behavior maintenance. Nurs Res, 45 (1):30-36. DOI: 10.1097/00006199-199601000-00006

Bozhüyük A., (2010). Çukurova Üniversitesi Sağlık Bilimleri Öğrencilerinin Sağlıklı Yaşam Biçimi Davranışlarının Değerlendirilmesi, Çukurova Üniversitesi Tıp Fakültesi Aile Hekimliği Anabilim Dalı Uzmanlık Tezi, Adana. https://tez.yok.gov.tr/UlusalTezMerkezi/ 
Cihangiroğlu, Z., \& Deveci, S. E. (2011). Healthy Life Style Behaviours and Related Influencing Factors of the Students of Elazig High School of Health Sciences of Firat University, Firat Medical Journal, $16 \quad$ (2),78-83. http://www.firattipdergisi.com/pdf/pdf_FTD_682.pdf

Çebi, M., \& İmamoğlu, O. (2018). The Healthy Lifestyle Behaviours of Students of Sport Science Faculty According to Gender, Journal of Sport Education, 2 (1), 12-20. https://dergipark.org.tr/tr/download/article-file/445856

Demir, Z., Korkmaz, N. H., \& Sevil, Ü. (2015). Examining healthy lifestyle behaviors of university students who do and do not exercise. International Refereed Academic Journal of Sports Health and Medical Sciences, 5 (14):96-109. https://www.sstbdergisi.com/

İmamoğlu, O., Çebi, M., İslamoğlu, İ. \& Yamak, B. (2018). Healthy Lifestyle Behaviors of Sedentary University Students, Akşemsettin International Human, Society and Sport Sciences Symposium, Proceeding Book, 06, 524-529. http://www.aksemseddinsempozyumu.org/

Jones, R., Britten, N., Culpepper L., Gass, D., Grol, R., Mant, D., \& Silagy C. (2004). Oxford Textbook of Primary Medical Care. New York: Oxford University Press.

Kafkas, M. E., Kafkas, A. Ş., Acet, M. (2012). Analysis of physical educatıon teachers' level of healthy life style behavious. Dumlupınar University Journal of Social Sciences, 32 (11), 51. https://www.academia.edu/13345259/

Karadamar M., Yiğit, R., \& Sungur, M. A. (2014). Evaluation of healthy lifestyle behaviours in adolescents, Anatolian Journal of Nursing and Health Sciences, 17 (3): 131-139. https://dergipark.org.tr/en/pub/ataunihem/issue/2666/34573

Karadeniz, G., Uçum, E. Y., Dedeli, Ö., \& Karaağaç Ö. (2008). Healthy lifestyle behaviors of university students, TAF Prev Med Bull, 7 (6),497-502. https://www.bibliomed.org/mnsfulltext/1/khb_007_06-497.pdf?1628099971

Kılıç, L. (2017). Beden eğitimi öğretmenlerinin sağlıklı yaşam biçim davranışlarının bazı değişkenlere göre değerlendirilmesi. Yüksek lisans tezi, İstanbul gelişim üniversitesi sağlık bilimleri enstitüsü, İstanbul. https://tez.yok.gov.tr/UlusalTezMerkezi/ 
Kocaakman M. (2010). Healthy life style behavior of the students at the nursing college in Istanbul, Süleyman Demirel University Faculty of Medicine Journal, 17 (2),1924. https://dergipark.org.tr/tr/pub/sdutfd/issue/21000/225780

O'Donnell M.P. (2009). Definition of health promotion 2.0: embracing passion, enhancing motivation, recognizing dynamic balance, and creating opportunities. Am J Health Promot, 24 (1) :iv. doi: 10.4278/ajhp.24.1.iv.

Özbaşaran F. Çetinkaya A.Ç., Güngör N. (2004). Health behaviors of students in school of health in Celal Bayar University, Journal of Atatürk University School of Nursing, 7 (3), 43-55. https://dergipark.org.tr/tr/download/article-file/29241

Özyazıcıŏ̆lu, N., Kılıç, M., Erdem, N., Yavuz, C., \& Afacan, S. (2011). Determinants of nursing students' healthy life style, International Journal of Human Sciences. 8 (2), 277-332. https://www.j-humansciences.com/ojs/index.php/IJHS/article/view/1401

Palank, C. L. (1991). Determinants of health-promotive behavior. A review of current research, Nurs Clin North Am. $26 \quad$ (4): 815-832. https://pubmed.ncbi.nlm.nih.gov/1945937/

Savucu, Y. (2020). Healthy life style behaviors. Journal of Sport and Recereation Researches, 2 (1), 34-43. https://dergipark.org.tr/tr/download/article-file/1116906

Sural, V., \& Tamer K. (2021). Examining the healthy lifestyle behaviors of physical education and sports teachers in terms of various variables. Gazi Journal of Physical Education and Sport Sciences, $26 \quad$ (1), 163-180. https://dergipark.org.tr/en/download/article-file/1382962

Şen, M. A., Ceylan, A., Kurt, M. E., Palancı, Y. \& Adın, C. (2017). Healthy lifestyle behaviours of vocational school of health services students and influential factors. Dicle Medical Journal, 44 (1), 1-11. DOI: 10.5798/dicletip.298567

Şimşek, H., Öztoprak, D., İkizoğlu, E., Safalı, F., Yavuz, Ö., Onur, Ö., Tekel Ş., \& Çiftçi Ş. (2012). Healthy lifestyle behaviours and related factors of medical school students. DEU Faculty of Medicine Journal, 26 (3), 151-157. https://jag.journalagent.com/deutip/pdfs/DEUTFD_26_3_151_157.pdf

Turan, M. B., Karaoğlu, B., \& Koç, K. (2017). Investigation of the relationship between university students' personal characteristics and success tendencies. The Turkish 
Online Journal of Educational Technology, Special Issue, 318-325. https://eric.ed.gov/?id=ED589568

Türkay, İ. K. (2020). Investigation of the Relationship between Self-Esteem and Healthy Lifestyle Behaviors of Physical Education and Sports Teaching Department Students. Mediterranean Journal of Sport Science, 3 (1), 108-117. Doi: 10.38021asbid.741277

Volden, C., Langemo, D., Adamson, M., \& Oechsle, L. (1990). The relationship of age, gender and exercise practices to measure of health, lifestyle, self-esteem. Appl.Nurs. Res. 3 (1):20-26. DOI: 10.1016/s0897-1897(05)80150-8

Volkan B. (2016). Beden eğitimi ve spor yüksek okulu öğrencilerinin sağlıklı yaşam biçimi davranışlarının beden kitle indeksi ve çeşitli değişkenler açısından incelenmesi. Yüksek lisans tezi, Kafkas üniversitesi fen bilimleri enstitüsü ilköğretim anabilim dalı, sağlık eğitimi bilim dalı, Kars. https://tez.yok.gov.tr/UlusalTezMerkezi/

Walker, S. N., Sechrist, K. R., \& Pender, N. J. (1987). The Health-Promoting Lifestyle Profile: development and psychometric characteristics. Nursing Research, 36 (2), 76-81. https://pubmed.ncbi.nlm.nih.gov/3644262/

World Health Organization, (2010). The Bangkok Charter for health promotion in a globalized world. Erişim. http://www.afro.who.int/en/tanzania/tanzaniapublications/cat_view/1501-english/1235-divisions-andprogrammes/

Yalcin, İ., Araz, G. Y., Ekinci, N. E., \& Birkok, C. M. (2020). The effect of sports attitude on healthy lifestyle behavior in university students. Progress in Nutrition, 22 (1), 66-71, DOI: 10.23751/pn.v22i1-S.9786

Zaybak A., Fadıloğlu Ç. (2004). Determining of The Health Promotion Behaviors of University Students and The Factors Affecting These Behaviors, Ege University School of Nursing Journal, $20 \quad$ (1),77-95. https://dergipark.org.tr/tr/pub/egehemsire/issue/49615/635912 